This item was submitted to Loughborough's Research Repository by the author.

Items in Figshare are protected by copyright, with all rights reserved, unless otherwise indicated.

\title{
Young ghosts: ethical and methodological issues of historical research in children's geographies
}

PLEASE CITE THE PUBLISHED VERSION

http://dx.doi.org/10.1080/14733285.2012.693838

PUBLISHER

(c) Taylor \& Francis

VERSION

AM (Accepted Manuscript)

LICENCE

CC BY-NC-ND 4.0

REPOSITORY RECORD

Mills, Sarah. 2019. "Young Ghosts: Ethical and Methodological Issues of Historical Research in Children's Geographies”. figshare. https://hdl.handle.net/2134/12145. 
This item was submitted to Loughborough's Institutional Repository (https://dspace.lboro.ac.uk/) by the author and is made available under the following Creative Commons Licence conditions.

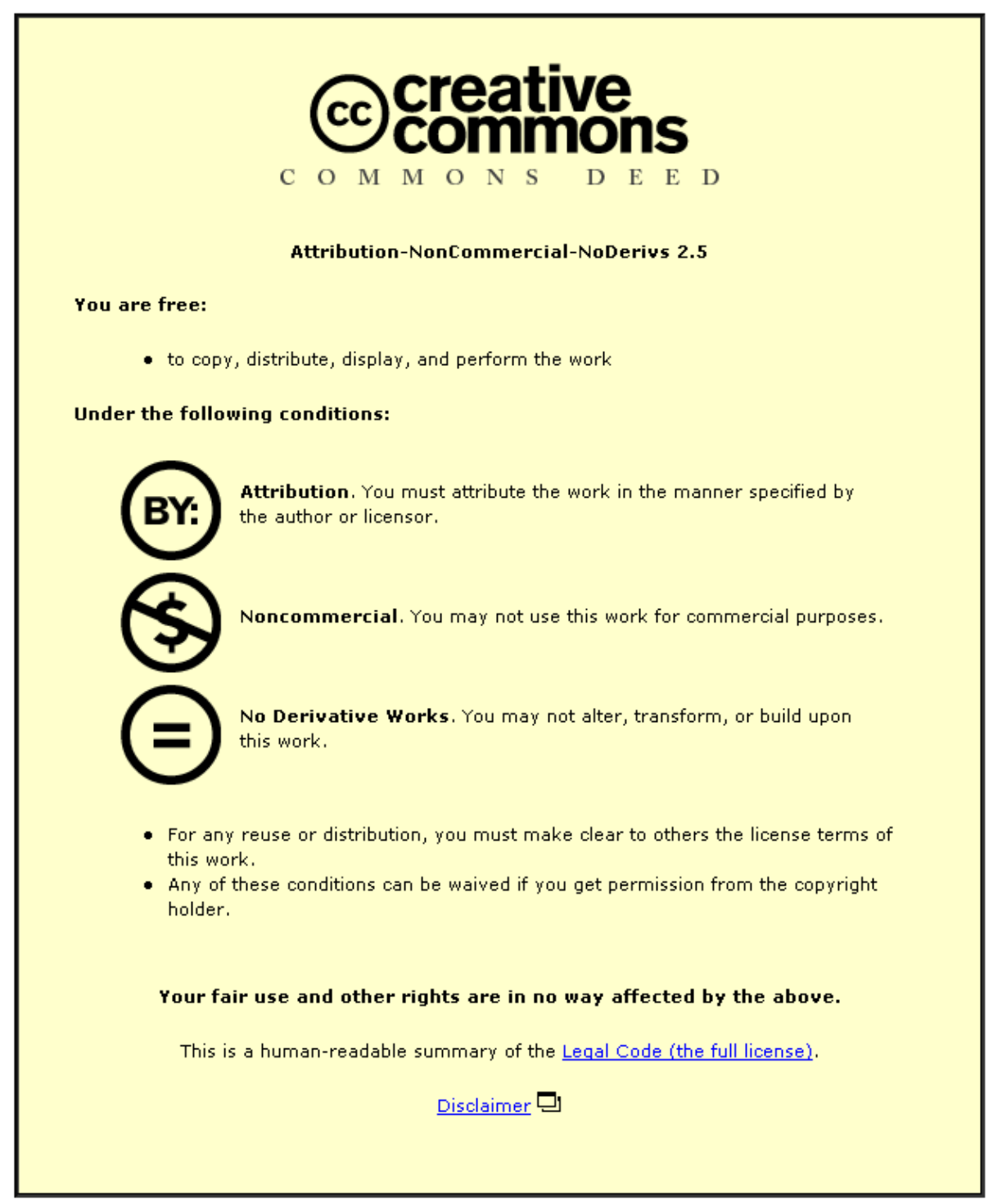

For the full text of this licence, please go to: http://creativecommons.org/licenses/by-nc-nd/2.5/ 


\title{
Young Ghosts: Ethical and Methodological Issues of Historical Research in Children's Geographies
}

\author{
Sarah Mills, Department of Geography, Loughborough University
}

To cite this paper:

Mills, S. (2012) Young Ghosts: Ethical and Methodological Issues of Archival Research in Children’s Geographies, 'Viewpoint' in Children's Geographies 10 (3): 357-363

\section{Introduction}

Geographers researching children and young people have often been at the forefront of disciplinary debates in geography surrounding methodological practice and ethical considerations (Matthews et al. 1998; Valentine 1999; Pain 2004; Hemming 2008; special issues ed. Van Blerk and Baker 2008; ed. Hopkins and Bell 2008). In this short paper, I want to focus on a less-popular research method used by children's geographers - archival methods (cf. Gagen 2000, 2001) - and reflect specifically on some of its methodological and ethical challenges. I argue that thinking about historical research can challenge children's geographers to consider other types of encounter from that of the (embodied) encounter between a researcher and a child (Horton 2008). These different and multiple encounters include those between the (adult) creator of 'material' and a young person, a young person (as creator) and their intended audience, and the further encounter between a young person from the past and a present-day researcher during fieldwork. The spatial and temporal deferral in some of these encounters suggests a re-thinking of how we approach and conceptualise research 'with' young people. Furthermore, these (dis)embodied encounters can challenge ethical norms in children's geographies such as consent, confidentiality and positionality in different but overlapping ways. I contend that children's geographers are well-versed in these ethical issues, some of which transfer well into the practice of historical research. For example, issues surrounding children's 'voice' and responsibility are quite similar (as I later discuss) but there is a difference between contemporary and historical research in terms of the media involved (your own tape recordings or someone else's recorded tapes; fresh participatory artwork or dust-covered diaries) and a different retrieval process (direct embodied research with young people or deferred connections in another building, time and place). 
Whilst historical geographers have begun to consider some of the ethics of archival research in the context of sensitive topics (Cameron 2001; Moore 2010) as part of a wider literature on historical research methods (Gagen et al. 2007; Lorimer 2009), this paper focuses on children and young people encountered in the archive. Drawing upon a series of scenarios and struggles from my doctoral research which examined the Scout Movement in Britain (1908 present), I consider how the historical geographies of young people bring a specific set of ethical responsibilities that need to be considered. The aim of this paper is two-fold: first, to initiate discussion on the ethical and methodological challenges for children's geographers utilising archival methods in their research, and second, to reflect on the wider implications of these challenges and highlight how a productive dialogue could take place between historical geographers and those engaged in research with young people. Indeed, there is a wider argument that could be made about the opportunities historical research presents for children's geographers more broadly. Before looking at two specific illustrations, I want to briefly reflect on the practice of historical research.

\section{'Hauntings' and the Politics of the Archive}

Historical research involves drawing upon partial remains or 'hauntings' of past lives, environments and practices made manifest in various secondary sources - material, recorded and visual - primarily located in archival collections. The endeavour of historical research, however, is often constricted by the politics of the archive and the nature and construction of certain types of knowledge (Burton 2005; Moore 2010). Elizabeth Gagen’s (2001) call to go beyond the representational politics of the archive by highlighting children's agency (in this case, within adult accounts of playground construction in early twentieth century US), hints at the possibilities for children's geographers to transform 'traditional' readings of archival material through tracing ‘moments’ of children’s contributions.

While archival research is the cornerstone of historical research, different methods (oral histories, life histories, biography) and other 'types' of archive (personal, photographic, online) have broadened the methodologies employed by historical geographers. My doctoral research considered the more-than-representational qualities of the archive, including written material, images, objects, textiles and oral histories as a collective (see also DeSilvey 2007; Lorimer and Whatmore 2009). These embodied historical geographies (Griffin and Evans 2008) examined, amongst other things, how Scouts used and appropriated various objects and 
material ephemera, creating unique engagements with the messages of scouting, as well as how certain individuals challenged and subverted the official politics of scouting through social and cultural difference.

The main body of this paper's discussion is now presented in two sections. These focus on specific 'moments' in my fieldwork that provoked ethical dilemmas. I have chosen these two examples specifically for their connections with familiar and ongoing debates in children's geographies, but to highlight the differences in the context of historical research. Indeed, whilst most ethical concerns in children's geographies could be seen as irrelevant when engaging in archival research, others chime well and prompt us to re-consider the ethics of 'doing' children's geographies. First, I discuss the role of certain individuals 'found' in the archive and the responsibilities of 'dealing with' these youthful voices; second, I reflect on issues of positionality, the emotional geographies of archival research, and unexpected connections with the present-day.

\section{Paul, Sybil and Marguerite: Biographies and Memories}

The first example concerns the role that certain individuals and biographies played in my doctoral research. Geographers have increasingly utilised biographies and life histories (Daniels and Nash 2004) and there is a growing literature exploring the connections between childhood, memory and (auto)biography (Brannen 2004; Karsten, 2005; Horton and Kraftl 2006). In my research, I aimed to intertwine the institutional with the personal through examining the lives of adults and young people who were crucial to scouting's emergence and negotiation of membership criteria. These included a minority of Scouts who held communist beliefs in the 1950s, one of whom - nineteen year old Paul Garland - was dismissed from his Scout Group in Bristol for his activities with the Young Communist League (Mills 2011a). I also drew on accounts of self-styled 'girl scouts' of various ages including Sybil from South London and Marguerite from Norfolk - who began in the very first years of scouting to engage with (and subvert) an organisation not intended for female youth (Mills 2011b). Although these biographical connections were often partial, in the sense they referred to a specific period in these young people's lives, they provided a unique insight into their experiences and relationships with scouting.

The use of personal and biographical details of people no longer alive, however, necessarily entailed a series of important ethical considerations, including issues surrounding privacy, 
confidentiality, consent, copyright and publication (on these issues in contemporary research with children, see Alderson and Morrow 2011). In terms of privacy, Moore (2010) rightly notes that these concerns are important for historical geographers exploring sensitive topics or criminal activity. In my research, however, the names of my 'research subjects' and their activities were already firmly in the public domain. How could I anonymise a Communist Scout that was named in hundreds of press reports and even a debate in the House of Lords? Indeed, should I have anonymised Paul and the other 'Red Scouts'? And how could I protect the privacy of 'girl scouts' whose names are listed in official histories, celebrating their role in the creation of the eventual Girl Guide Association? Anyone who could perform a quick internet search would have found the real identities of these individuals, despite my best efforts. Therefore, dealing with research subjects where these strategies were impractical, I struggled with what to 'do' with Paul, Sybil, Marguerite and others. It was therefore essential to carefully consider how I represented these individuals - frozen in time as young people. I strove to employ a reflexive approach to the research and be sensitive when dealing with personal information. I also paid careful attention to clarity and rigour in the narratives and quotations I used, checking data from a number of other sources and archival collections to avoid mistakes. It is clear though, that there is still much scope for debate about issues of privacy and biographical data in explorations of the historical geographies of young people.

I also want to reflect on issues of representation and consent. As geographers involved in 'mainstream' research with young people often experience, I felt a great sense of responsibility to these individuals (although they 'lived' in catalogues and boxes) and was often frustrated with the challenge of doing them justice. Carolyn Steedman has reflected on this element of archival research using the metaphor of dust:

\footnotetext{
"You think: these people have left me the lot: each washboard and doormat purchased; saucepans, soup tureens, mirrors, newspapers, ounces of cinnamon and dozens of lemons...Everything...You think: I could get to hate these people; and then: I can never do these people justice; and finally: I shall never get it done."

(Steedman 2001, 17-18, emphasis in original)
}

The realities of this seemingly insurmountable task are further complicated, I would argue, when this process involves young people. I felt this pressure was intensified as children in the archive were, in some ways, doubly-marginalised: first, as 'out-of-sight' research subjects housed in filing cabinets and on microfiche, and second, as young people hidden amongst 
adult-accounts (on issues of powerlessness and 'voices' of children, see Jones 2001; Holt 2004). We can also think about other social groups whose presence and position in the archive challenges researchers (women, people with disabilities, ethnic minorities) and I would argue that these ethical dilemmas need more attention in the geographical literature. Furthermore, at certain points, I was told by the archivist that some of the files I had requested had "never been seen before", which created an even stronger sense of responsibility. In these cases, I felt obliged not only to read this material more closely, but also to write about and (where appropriate) prioritise these events, stories and lives that had been hidden for decades.

The 'vulnerabilities' of young people in the archive were also impounded by issues of consent. Sybil, Paul and others were not able to give permission to be part of the research and were unable to participate, clarify or defend themselves in the process. Furthermore, the absence of a parent or guardian to safeguard them, or to give permission to 'become' research participants on their behalf, was a further dilemma. With these concerns in mind, I began to view the archivists as crucial in this gap and I would argue that their role and advice should not be overlooked in terms of gaining permission and accessing (past) young lives. There is also a broader debate here about the politics of the archive and hermeneutics; issues of consent and procedures around depositing material have changed over time, as has the role and uses of archives throughout the last century.

Another way I addressed some of these concerns about 'co-opting' individuals into the research project was to utilise oral histories when opportunities presented themselves (Riley and Harvey 2007). Although all of the individuals I used in my data collection were now deceased, in the case of the early girl scouts, a series of interviews had been recorded by the Girl Guide Association in the 1970s with some of these 'pioneers'. These (adult) childhood memories fleshed out some of the detail that written sources could not provide about the experiences of 'self-styled’ girl scouts:

I found that there were scouts going to have fun and games on Peckham Rye and talking it over with my schoolfriends, we decided that we should like to do the same...the more the merrier - we were just girls wanting to do the same as the boys.

(Sybil Cannadine, 1977, Girlguiding UK Archive) 
It was a mixed patrol, we had two little boys, I think four little girls. I can't remember the exact number... and we used to do Scouting... we used to take the sheets and turn them into tents, and cook, it was all cooking and outdoors.

(Marguerite de Beaumont, 1978, Girlguiding UK Archive)

These oral histories with (at the time) elderly women, gave me as a researcher an additional layer to explore how their activities as young girls called into question and subverted the original citizenship project of 'Scouting for Boys'. It is worth noting, however, that I still faced ethical dilemmas about including these recorded oral history extracts in terms of consent. Again, the archivist was helpful in discussing these ideas and there is a broader academic debate to have about the ethics of using previously recorded oral histories.

Finally, I want to reflect on what happens to these individuals after the research project has ended. In many ways, I still find myself 'haunted' by these individuals: they 'pop-up' in conference presentations, papers and discussions with colleagues. I refer to them often, know much about their lives, and yet have never met them. I now find myself questioning where to 'put' these individuals, or when it is time to 'let them go'. This emotional disclosure may be surprising to the reader, but I include it to highlight a neglected element of historical research practice and to show the connection with a familiar, or perhaps at least recognisable, feature of geographical research with children in the here-and-now. In thinking about how most contemporary research projects within children's geographies have mechanisms that communicate 'back' to research participants in creative and innovative ways, I am left wondering whether historical geographers could continue relationships after their projects have finished and what these 'participatory historical geographies' might look like.

\section{Moments in the archive: encountering objects and making connections}

The second example I wish to draw upon relates to issues of positionality and connections that flow between the archive and the outside world. It is important to consider the emotional and embodied experiences of archival fieldwork, as Burton argues, "the material spaces of archives exert tremendous and largely unspoken influences on their users, producing knowledge and insights which in turn impact the narratives they craft and the histories they write” $(2005,10)$. In terms of personal encounters with the archive, I experienced a series of emotions and sensations: solitude, repetitiveness, the thrill of discovery and dejection of lost causes. These were most powerful at the Scout Association where I undertook most of my fieldwork and can be illustrated here through the example of encounters with objects. 
In terms of the thrill and wonder, (re)discovering new or lost objects was exciting and often distracting. This included finding well-worn books signed with a child's name, a toy donated by a widow of an ex-scouter arriving in the archivist's post, and finding secret notes and jokes between leaders and old friends hidden inside boxes. These moments prompted me to seriously consider the ethics of the material I was privy to, alone, in the archive. I began to wonder whether anyone could possibly have imagined that the objects they once owned as a child would end up in this room, catalogued, photographed and studied by researchers. Furthermore, I reflected on what has (or will happen) to similar objects from my childhood? (on materialities and childhood memories, see Horton and Kraftl 2006). The dejection of lost causes was, conversely, disheartening. For example, the many occasions I followed missed leads and was out-bid on eBay for items of scout history (on the possibilities and dilemmas of historical geographers using eBay, see DeLyser et al. 2004). While these specific encounters and settings were unique and personal, the experiences of archival research are increasingly seen as part of methodological considerations in historical geography. For children's geographers then, some of these issues could be useful in extending and enlivening debates on memory, childhood, materialities, embodiment and (auto)biography.

It was also important to be reflexive throughout my fieldwork and, just like other research in children's geographies, to consider my positionality in relation to the project. My role as a researcher was complicated and yet enhanced by my position as a volunteer Scout Leader both before and during the research process. Although my research project was not focused on volunteering or contemporary scouting, and did not involve my Scout Group in a participatory context, I still experienced unexpected moments of translation from the archive (Bailey et al. 2009). Indeed, these distinct and separate responsibilities became linked and influenced by one another. Some of these connections were logistical: having to reschedule camp-dates I was due to go on to conduct fieldwork; some were anecdotal: holding conversations with the archivist about my own scouting experiences; and some were unexpected: informing my material and programme ideas as a Leader, as can be seen here in an extract from my field diary:

This morning [the archive assistant] asked me if I'd like some spare copies of duplicate books she had (mainly game and training skills manuals, c.1930s/40s). I couldn't resist (my bag was so heavy on the train tonight!) and some look really useful, particularly the images in Campfire Leaders Book (chapter 
4?). I've earmarked a couple of games from one book to play at Cubs when I get home. Another has a design variation on the catapult made at last year's Fun Day in Trawscoed that would perhaps work better next year (don't forget to photocopy for the Scout Hut).

(Field diary extract, 19/08/08)

And so, these dual-roles would often merge and mix, with historical and contemporary scouting becoming part of my everyday routines of researching and volunteering. There was, however, a clear distinction between what I identified as the research project and what I saw as my duties as a Scout Leader. This point is made, however, to show how the archive is not simply a 'repository', but can influence and inform contemporary practices. Indeed, this is one reason why I argue it is necessary for researchers to respect young people in the archives in similar ways to young people in the here-and-now.

There were also unconscious and surprise connections that revealed themselves as the fieldwork expanded. For example, I discovered that Paul Garland - the Communist Scout mentioned earlier - was a Queen's Scout (a recipient of the highest award in scouting to a young person under twenty-five) at the same time I was undertaking this award myself. Conducting the activities and requirements of this award, whilst simultaneously reading about how Garland was stripped of his award for his political beliefs, was one example where the past lives of those encountered in the archive related to my own experiences as a Scout and complicated my relationship with the organisation. Other connections drew emotional responses: the moving accounts of 'unauthorised' girl scouts in the 1970s and 1980s who were removed from Scout Groups, yet played a key part in the eventual policy change to allow co-education in 1990 - a decision that facilitated my move from guiding to scouting as the first girl scout at my home Scout Group aged fifteen. It is worth taking seriously, therefore, how these personal and lifelong connections with the organisation influenced (in part) my examination of its histories and past members.

\section{Conclusion}

Geographers have ethical responsibilities towards the people whose lives we seek to interpret and reconstruct in our research. This paper has reflected on one experience of the process of doing archival research within children's geographies and to initiate discussion on the ethical dilemmas it provoked. It has shown how young people's voices from the past deserve as 
much respect, sensitivity and informed thinking from geographers as when dealing with young people's voices in contemporary research.

This piece was stimulated by recent debates in historical geography on the methodological challenges of archival research, and the continued debates in children's geographies on ethical and methodological practice. This piece has therefore brought together what may have been seen as disparate sub-disciplinary debates, however, it is clear that there are connections here that could be explored in more detail. Indeed, questions of privacy, consent, interpretation and positionality hint at a further, mutually-beneficial, dialogue that could take place between historical geographers and those researching the lives of children and young people. There is also scope for a fuller discussion of what a historical perspective might do to challenge conventions of working in children's geographies. Overall, the issues discussed in this paper extend beyond sub-disciplinary boundaries and are pertinent for the discipline more broadly in order to move toward more ethically sound and considered research practices.

\section{References}

Alderson, P. and Morrow, V., 2011. The ethics of research with children and young people: a practical handbook London: SAGE.

Bailey, A.R., Brace, C., Harvey, D.C., 2009. Three geographers in an archive: positions, predilections and passing comment on transient lives. Transactions of the Institute of British Geographers, 34 (2), 254-269.

Brannen, J., 2004. Childhoods across the generations: stories from women in four-generation English families. Childhood, 11 (4), 409-428.

Burton, A., Ed. 2005. Archive stories: facts, fictions and the writing of history. Durham; London: Duke University Press.

Cameron, L., 2001 Oral history in the Freud archives: incidents, ethics and relations. Historical Geography, 29, 38-44.

Daniels, S. and Nash, C., 2004. Lifepaths: geography and biography. Journal of Historical Geography, 30 (3), 449-458.

DeLyser, D., Sheehan, R. and Curtis, A., 2004. eBay and research in historical geography. Journal of Historical Geography, 30 (4), 764-782.

DeSilvey, C., 2007. Salvage memory: constellating material histories on a hardscrabble homestead. Cultural Geographies, 14 (3), 401-424. 
Gagen, E.A., 2000. An example to us all: child development and identity construction in early 20th-century playgrounds. Environment and Planning A, 32 (4), 599-616.

Gagen, E.A., 2001. Too good to be true: representing children's agency in the archives of playground reform. Historical Geography, 29, 53-64.

Gagen, E.A., Lorimer, H. and Vasudevan, A., 2007. (eds) Practising the Archive: Reflections on Methods and Practice in Historical Geography. Historical Geography Research Series, no.40. London: Royal Geographical Society/IBG

Griffin, C.J. and Evans, A.B., 2008. Historical Geographies of Embodied Practice and Performance. Historical Geography, 36, 5-16.

Hemming, P.J., 2008. Mixing qualitative research methods in children's geographies. Area, 40 (2), 152-162.

Hopkins, P.E., and Bell, N., 2008. Interdisciplinary perspectives: ethical issues and child research. Children's Geographies 6 (1), 1-6.

Holt, L., 2004. The 'Voices' of Children: De-centring Empowering Research Relations, Children's Geographies, 2 (1), 13-27.

Horton, J., 2008. A 'sense of failure'? Everydayness and research ethics. Children's Geographies, 6 (4), 363-383.

Horton, J., and Kraftl, P., 2006. Not just growing up, but going on: children's geographies as becomings: materials, spacings, bodies, situations. Children's Geographies, 4 (3), 259-276.

Jones, O., 2001. 'Before the dark of reason': Some ethical and epistemological considerations on the otherness of children. Ethics, Place and Environment, 4 (2), 173-178.

Karsten, L. 2005. It all used to be better? Different generations on continuity and change in urban children’s daily use of space. Children's Geographies, 3 (3), 275-290.

Lorimer, H., 2009. Caught in the nick of time: archives and fieldwork. In: S. Aitken, M. Crang, D. DeLyser, S. Herbert and L. McDowell, eds. The SAGE Handbook of Qualitative Geography London: SAGE, 248-272.

Lorimer, J. and Whatmore, S., 2009. After the 'king of beasts': Samuel Baker and the embodied historical geographies of elephant hunting in mid-nineteenth century Ceylon. Journal of Historical Geography, 35 (4), 668-689.

Matthews, H., Limb, M. and Taylor, M., 1998. The geography of children: Some ethical and methodological considerations for project and dissertation work. Journal of Geography and Higher Education, 22 (3), 311-324.

Mills, S., 2011a. Be Prepared: Communism and the Politics of Scouting in 1950s Britain. Contemporary British History, 25 (3), 429-450. 
Mills, S., 2011b. Scouting for Girls? Gender and the Scout Movement in Britain. Gender, Place and Culture: A Journal of Feminist Geography, 18 (4), 537-556.

Moore, F.P.L., 2010. Tales from the archive: methodological and ethical issues in historical geography research. Area, 42 (3), 262-270.

Pain, R., 2004. Social geography: participatory research. Progress in Human Geography, 28 (5), 652-663.

Riley, M. and Harvey, D., 2007. Talking geography: on oral history and the practice of geography. Social and Cultural Geography, 8 (3), 345-351.

Steedman, C. 2001. Dust: The archive and cultural history Manchester: Manchester University Press

Valentine, G., 1999. Being seen and heard? Ethical dilemmas of research with children and young people. Ethics, Place and Environment, 2 (2), 141-155.

Van Blerk, L. and Barker, J., 2008. The wider relevance of undertaking research with children, Guest Editorial, Children’s Geographies, 6 (2), 117-119. 